\title{
School Gardens in the Distrito Federal, Brazil
}

\section{Hortas escolares no Distrito Federal, Brasil}

Renata BERNARDON²

Bethsáida de Abreu Soares SCHMITZ2

Elisabetta Gioconda Iole RECINE ${ }^{2}$

Maria de Lourdes Carlos Ferreirinha RODRIGUES ${ }^{2}$

Cristine Garcia GABRIEL ${ }^{3}$

A B S T R A C T

\section{Objective}

The aim of the present study was to identify experiences with gardens in public schools in the Distrito Federal, Brazil, and to analyze factors involved in their use to promote healthy eating habits.

\section{Methods}

This is an analytical cross-sectional study with data collection in two phases: (1) telephone contact with all public schools in the Distrito Federal; (2) interviews conducted with a sample of schools with a garden $(n=105)$.

\section{Results}

Of the 582 schools in the Distrito Federal, 453 (77.8\%) participated in phase 1 and $37.7 \%$ of these had a garden. Rural schools had a higher prevalence of gardens $(p=0.003)$. Among the schools which had no garden, $75.2 \%(n=212)$ had interest in creating one. The main reason for the deactivation of gardens was a lack of manpower to maintain them. The main reason for creating a garden was to supplement school food (56.2\%). The garden was used as an educational space to promote healthy eating habits by $60.8 \%$ of the schools.

\section{Conclusion}

An expressive percentage of schools with gardens (37.7\%) was identified in the Distrito Federal. A number of factors were associated with the presence of a garden, including the location and size of the school, as well as the level of education. A significant percentage of schools reported using the garden as a space to promote healthy eating habits. This result must be refined by assessing the use and impact of gardens as a tool to promote healthy eating habits in the school community.

Indexing terms: Food and nutrition education. Health promotion. Schools.

\footnotetext{
1 Article based on the dissertation of the R BERNARDON intitled "Horta escolar no Distrito Federal: instrumento de promoção da alimentação saudável". Universidade de Brasília; 2011.

2 Universidade de Brasília, Faculdade de Ciências da Saúde, Programa de Pós-Graduação em Nutrição Humana. Brasília, DF, Brasil.

3 Universidade Federal de Sergipe, Centro de Ciências Biológicas e da Saúde, Departamento de Nutrição. Av. Marechal Rondon, s/n., Jardim Rosa Elze, 49100-000, São Cristóvão, SE, Brasil. Correspondência para/Correspondence to: CG GABRIEL. E-mails: <cris_ntr@hotmail.com>; <criggabriel@yahoo.com.br>.
} 


\section{RE S U M O}

\section{Objetivo}

Identificar experiências com hortas em escolas públicas do Distrito Federal, Brasil, analisando determinantes no seu uso voltado à promoção da alimentação saudável.

\section{Métodos}

Estudo transversal analítico, com coleta de dados em duas fases: (1) por telefone com todas as escolas públicas do Distrito Federal; (2) entrevista presencial com amostra das escolas que possuíam horta $(n=105)$.

\section{Resultados}

Das 582 escolas do Distrito Federal, 453 (77,8\%) participaram da fase 1 e dessas, 37,7\% possuíam horta. Escolas rurais apresentaram maior prevalência de horta $(p=0,003)$. Das escolas sem horta, 75,2\% tinham interesse na sua implantação. O principal motivo para desativação da horta foi falta de mão-de-obra para manutenção. Quanto às escolas com horta, a intenção de complementar a alimentação escolar foi o principal motivo de sua implantação (56,2\%). A horta era utilizada como espaço educativo para promoção da alimentação saudável por $60,8 \%$ das escolas.

\section{Conclusão}

Foi identificado no Distrito Federal um percentual expressivo de escolas com horta (37,7\%). Alguns fatores relacionados à localização, porte e nível de ensino da escola associaram-se à presença da horta. Verificou-se inicialmente, um elevado percentual de escolas que relataram utilizar a horta como espaço de promoção da alimentação saudável. Faz-se necessário aprofundar este resultado por meio de avaliação do uso e impacto da horta como instrumento de promoção da alimentação saudável na comunidade escolar.

Termos de indexação: Educação alimentar e nutricional. Promoção da saúde. Instituições acadêmicas.

\section{NTRODUCTION}

Brazilian food consumption data indicate excessive intake of foods with a high sugar, fat and sodium content, as well as a reduction in the consumption of protective foods, such as fruit and vegetables ${ }^{1}$. This has also been observed among children and adolescents in schools. A study in Rio de Janeiro (RJ) assessed children from the $8^{\text {th }}$ grade of a public school and confirmed a high consumption of candy, soft drinks, fried and salted food, with a low consumption of fruit and vegetables ${ }^{2}$. A study in Piracicaba (SP) assessed the eating habits of adolescents from 10 to 17 years of age and reported that $84 \%$ of them exhibited an energy intake above the recommended levels (37\% lipids) ${ }^{3}$. Similarly, a reduction was confirmed in the rates of malnutrition and deficiency diseases, with increases recorded in the prevalence of overweight or obese adolescents. This epidemiological situation demands new strategies focused on health promotion $^{4,5}$.
The promotion of healthy eating habits in the school environment presupposes the development of educational activities that help and motivate the adoption of healthy eating habits ${ }^{6}$. School gardens offer potential integration for several health determinants (eating habits, physical activity and social interaction) in a single activity and can be used as a nutritional education instrument and an important pedagogical resource for the school ${ }^{7-9}$.

The aim of the present study, conducted in the Distrito Federal (DF) where Brazil's capital city is located, was to assess experiences with public school gardens and to identify the determinants of their use as a strategy to promote healthy eating habits. The authors of the present study hope to contribute to the knowledge and assessment of factors that could guide the management of different government spheres, facilitating the planning, stimulation and guidance of this type of activity. 


\section{METHODS}

This is a cross-sectional analytical study of public schools in the 25 administrative regions of the DF, Brazil. The factors assessed were associated with the presence or absence of a garden in these schools. The data were collected between August 2008 and July 2009. The research was divided into two phases: phase 1 involved mapping the gardens in the DF, based on the available public schools; phase 2 involved characterizing the use of the gardens, based on the schools that had a garden. This information was obtained from the phase 1 data.

The study population in phase 1 was constituted of an initial figure of 582 public schools, registered with the Instituto Nacional de Estudos e Pesquisas Educacionais (INEP) and the Secretaria de Educação do Distrito Federal in January 2008. Due to the impossibility of telephone contact with a number of these schools, this total number was reduced to 576 schools. Of these schools, 15 (2.6\%) were excluded because they had already participated in the pilot phase and 93 (16.6\%) others were excluded based on the exclusion criteria, which will be clarified shortly. Therefore, the present study began with a total of 453 schools $(77.8 \%$ of the initial figure).

Considering that in phase 1, $171(37.7 \%)$ schools reported having a garden, a representative sample of these schools was selected for phase 2 $(n=105)$, based on simple random sampling, establishing a maximum sampling error of $6.0 \%$. The sample calculations took into consideration the administrative regions of the DF.

The 15 schools that were involved in the pilot study were selected randomly and four of them contained a garden. Important observations were made regarding the instruments in an attempt to ensure a better applicability of the same.

As well as participation in the pilot study, the following exclusion criteria were applied in phase 1: three unsuccessful attempts to make telephone contact at different times on different days; altered telephone number and refusal to participate in the study. In phase 2, two further criteria were considered: address not found; absence of a garden or an inactive garden.

Two instruments were developed for data collection. The phase 1 instrument was applied based on telephone contact with a coordinator or manager of the school's pedagogical projects and involved a semi-structured questionnaire, with variables organized in two blocks: (i) identification and characterization of the school and (ii) presence of a school garden. The first block contained questions about the location of the school, the teaching methods, the operating shifts, the presence or absence of a garden, among others, and was used for all schools. If there was no garden in the school, the second block of questions were applied by the interviewer, seeking the following information: the presence of a garden at some stage in the school's past or present; interest in implementing a garden and garden implementation projects. Schools without a garden took no further part in the study after this phase. After finishing the first block of questions, a visit was requested to schools with a garden. This visit was requested in order to apply the phase 2 instrument.

Phase 2 was carried out in person using a semi-structured questionnaire divided into four discussion points: (i) implementation, maintenance and cultivation of the garden; (ii) complementing school nourishment; (iii) participation of the school community, and (iv) the garden as an instrument that promotes healthy eating habits. The interviews were preferably conducted with the staff member who was responsible for the garden or who created the garden project.

Data were double entered in Statistical Package for the Social Sciences (SPSS) software, version 17.0. The answers to the open questions were transcribed textually and categorized in common themes. Statistical analysis was performed using descriptive statistics, the 
Student's $t$ test and Pearson's Chi-squared test. In addition, a logistical regression model was designed, composed of variables of practical significance for the present study. Controlled regression was applied to the presence of a garden in relation to the location of the school, the level of education, the operating shifts, the quantity of students, teachers, staff and groups, and the presence of a commercial snack bar. The results were considered statistically significant if $p<0.05$.

Pre-requisites were defined for the construction of a garden and the presence of a non-cemented space and a green area of at least $1.20 \mathrm{~m} \times 2 \mathrm{~m}^{8,10}$.

The present study was approved by the Research Ethics Committee of the Health Sciences Faculty in the Universidade de Brasilia (UnB) under Protocol number 006/2005 on May 17, 2005. All participants signed an Informed Consent Form.

\section{RE S U L T S}

\section{Phase 1: Characterization of schools in relation to the presence or absence of a garden}

The 453 schools that participated in phase 1 operated a morning schedule, whereas 95.6\% also operated in the evening and $25.6 \%$ also operated at night. In total, $93.4 \%$ of the schools were located in urban areas. Rural schools were present in nine of the 25 regions (data not shown in the tables). Of the 453 schools, $37.7 \%$ had a garden. The presence of a garden was more significant in rural schools than in urban schools (63.3\% versus $35.9 \% ; p=0.003$ ) (Table 1).

Schools that were involved in pre-school and crèche activities more commonly contained a garden, which is contrary to the results found in high schools ( $p=0.004$ ) (Table 1).

Among the 282 schools without a garden, $57.1 \%$ reported having a garden at some time in the past and $75.2 \%$ expressed an interest in implementing a garden in the future. When questioned about the existence of a project to implement a garden, $26.9 \%$ of urban schools and $45.5 \%$ of rural schools confirmed that they had one in place (Table 1).

The majority of urban schools (87.4\%) and rural schools (81.8\%) possessed at least one prerequisite for the construction of a garden $(66.4 \%$ of urban schools had one requisite and 20.2\% had two). Only $12.8 \%$ of the schools had no requisites at all (Table 2 ). Having one of the prerequisites could be a determining factor in the implementation of a garden since only $3.1 \%$ of the schools that already had a garden had no pre-requisite available at the time of the research $(p<0.001)$. In addition, only $6.1 \%$ of the schools interested in creating a garden did not have prerequisites $(p<0.001)$.

Upon comparison of schools with a garden and schools that had one in the past, there was a greater prevalence of gardens in schools with less students $(p<0.001)$, less teachers $(p=0.012)$, less staff ( $p=0.005)$ and less groups $(p=0.046)$ (Table 3).

The main reason for abandoning a garden was the lack of staff to maintain it, which constituted $42.9 \%$ of the responses $(n=69)$ (data not shown in the tables).

Table 4 displays the variables that exerted an influence on the presence of a garden. The chance of the school having a garden was 2.35 times greater in rural areas. Schools with more students were less likely to have a garden. If a school increased its student numbers by 100 , the chances of having a garden fell by $6 \%$ (1 - 0.94).

\section{Phase 2: Characterization of the schools with gardens}

The main reasons for creating a garden were the following: Intention to complement nourishment (56.2\%); take advantage of the space to work with students (46.7\%) and; use 
Table 1. Characterization of public schools in relation to the school garden, location and education levels. Distrito Federal, Brazil, 2008-2009.

\begin{tabular}{|c|c|c|c|c|c|c|c|}
\hline \multirow{3}{*}{ Characteristics } & \multicolumn{7}{|c|}{ Presence of a school garden at the time of the research } \\
\hline & \multicolumn{2}{|c|}{ Yes } & \multicolumn{2}{|c|}{ No } & \multicolumn{2}{|c|}{ Total } & \multirow{2}{*}{$p^{\mathbf{a}}$} \\
\hline & $n$ & $\%$ & $n$ & $\%$ & $n$ & $\%$ & \\
\hline \multicolumn{8}{|l|}{ Location } \\
\hline Urban Area & 152 & 35.9 & 271 & 64.1 & 423 & 100.0 & 0.003 \\
\hline Rural Area & 19 & 63.3 & 11 & 36.7 & 30 & 100.0 & \\
\hline Total & 171 & 37.7 & 282 & 62.3 & 453 & 100.0 & \\
\hline \multicolumn{8}{|l|}{ School Level } \\
\hline Pre-school & 60 & 42.3 & 82 & 57.7 & 142 & 100.0 & 0.181 \\
\hline Crèche & 7 & 43.8 & 9 & 56.2 & 16 & 100.0 & 0.614 \\
\hline Elementary School & 136 & 37.5 & 227 & 62.5 & 363 & 100.0 & 0.803 \\
\hline High School & 13 & 21.3 & 48 & 78.7 & 61 & 100.0 & 0.004 \\
\hline \multirow[t]{2}{*}{ Others } & 42 & 36.8 & 72 & 63.2 & 114 & 100.0 & 0.818 \\
\hline & \multicolumn{7}{|c|}{ Presence of a school garden prior to the research ${ }^{\mathbf{b}}$} \\
\hline \multicolumn{8}{|l|}{ Location } \\
\hline Urban Area & 152 & 56.1 & 119 & 43.9 & 271 & 100.0 & \\
\hline Rural Area & 9 & 81.8 & 2 & 18.2 & 11 & 100.0 & 0.091 \\
\hline Total & 161 & 57.1 & 121 & 42.9 & 282 & 100.0 & \\
\hline \multicolumn{8}{|l|}{ School Level } \\
\hline Pre-school & 49 & 59.8 & 33 & 40.2 & 82 & 100.0 & 0.563 \\
\hline Crèche & 5 & 55.6 & 4 & 44.4 & 9 & 100.0 & 0.925 \\
\hline Elementary School & 136 & 59.9 & 91 & 40.1 & 227 & 100.0 & 0.052 \\
\hline High School & 25 & 52.1 & 23 & 47.9 & 48 & 100.0 & 0.441 \\
\hline \multirow[t]{2}{*}{ Others } & 41 & 56.9 & 31 & 43.1 & 72 & 100.0 & 0.977 \\
\hline & \multicolumn{7}{|c|}{ Interest in creating a garden ${ }^{\mathbf{b}}$} \\
\hline \multicolumn{8}{|l|}{ Location } \\
\hline Urban Area & 202 & 74.5 & 69 & 25.5 & 271 & 100.0 & \\
\hline Rural Area & 10 & 90.9 & 1 & 0.9 & 11 & 100.0 & 0.218 \\
\hline Total & 212 & 75.2 & 70 & 24.8 & 282 & 100.0 & \\
\hline \multicolumn{8}{|l|}{ School Level } \\
\hline Pre-school & 65 & 79.3 & 17 & 20.7 & 82 & 100.0 & 0.309 \\
\hline Crèche & 6 & 66.7 & 3 & 33.3 & 9 & 100.0 & 0.548 \\
\hline Elementary School & 188 & 82.8 & 39 & 17.2 & 227 & 100.0 & $<0.001$ \\
\hline High School & 33 & 68.7 & 15 & 31.3 & 48 & 100.0 & 0.258 \\
\hline \multirow[t]{2}{*}{ Others } & 48 & 66.7 & 24 & 33.3 & 72 & 100.0 & 0.053 \\
\hline & \multicolumn{7}{|c|}{ Existence of plans to create a garden ${ }^{\mathbf{b}}$} \\
\hline \multicolumn{8}{|l|}{ Location } \\
\hline Urban Area & 73 & 26.9 & 198 & 73.1 & 271 & 100.0 & \\
\hline Rural Area & 5 & 45.5 & 6 & 54.5 & 11 & 100.0 & 0.178 \\
\hline Total & 78 & 27.7 & 204 & 72.3 & 282 & 100.0 & \\
\hline \multicolumn{8}{|l|}{ School Level } \\
\hline Pre-school & 28 & 34.1 & 54 & 65.9 & 82 & 100.0 & 0.119 \\
\hline Crèche & 2 & 22.2 & 7 & 77.8 & 9 & 100.0 & 0.711 \\
\hline Elementary School & 74 & 32.6 & 153 & 67.4 & 227 & 100.0 & $<0.001$ \\
\hline High School & 11 & 22.9 & 37 & 77.1 & 48 & 100.0 & 0.420 \\
\hline Others & 19 & 26.4 & 53 & 73.6 & 72 & 100.0 & 0.780 \\
\hline
\end{tabular}

Note: ${ }^{a}$ Chi-squared test. ${ }^{b}$ Data referring to schools without a garden at the time of the research. 
the space for food nutrition education (14.3\%). The main supporters of school gardens were teachers $(30.5 \%)$ and management $(23.8 \%)$.
Once installed, 89.5\% ( $n=94$ ) reported appointing a person to look after the garden, usually teachers $(45.7 \%)$, cleaning staff (33.0\%) or students (23.4\%).

Table 2. Distribution of public schools that do not have a garden according to the presence of requisites for creation. Distrito Federal, Brazil, 2008-2009.

\begin{tabular}{|c|c|c|c|c|c|c|c|}
\hline \multirow{3}{*}{$\begin{array}{l}\text { Non-cemented space } \\
\text { Yes }\end{array}$} & \multicolumn{6}{|c|}{ Green area of $1.20 \mathrm{~m} \times 2 \mathrm{~m}^{\mathrm{a}}$} & \multirow{3}{*}{$p^{\mathbf{b}}$} \\
\hline & \multicolumn{2}{|c|}{ Yes } & \multicolumn{2}{|c|}{ No } & \multicolumn{2}{|c|}{ Total } & \\
\hline & 57 & 20.2 & 91 & 32.3 & 148 & 52.5 & \\
\hline No & 98 & 34.8 & 36 & 36.0 & 134 & 47.5 & $<0.001$ \\
\hline Total & 155 & 55.0 & 127 & 45.0 & 282 & 100.0 & \\
\hline
\end{tabular}

Note: ${ }^{a}$ Criteria for the existence of the garden. ${ }^{\mathbf{b}}$ Chi-squared test.

Table 3. Characterization of public schools in terms of the variables related to the garden, according to the number of students, teachers, staff and groups. Distrito Federal, Brazil, 2008-2009.

\begin{tabular}{|c|c|c|c|c|c|}
\hline \multirow{3}{*}{ Characteristics } & \multicolumn{5}{|c|}{ Presence of a school garden at the time of the research } \\
\hline & \multicolumn{2}{|c|}{ Yes } & \multicolumn{2}{|c|}{ No } & \multirow{2}{*}{$p^{\mathbf{a}}$} \\
\hline & $M$ & SD & $M$ & SD & \\
\hline \multicolumn{6}{|l|}{ Number } \\
\hline Students & 745.0 & 530.6 & $1,036.0$ & 791.1 & $<0.001$ \\
\hline Teachers & 35.2 & 25.8 & 43.1 & 33.1 & 0.005 \\
\hline Staff & 51.4 & 31.0 & 63.4 & 61.5 & 0.020 \\
\hline Groups & 25.9 & 16.9 & 29.4 & 17.0 & 0.033 \\
\hline & \multicolumn{5}{|c|}{ Presence of a school garden prior to the research ${ }^{\mathbf{b}}$} \\
\hline \multicolumn{6}{|l|}{ Number } \\
\hline Students & $1,020.1$ & 732.1 & $1,057.1$ & 866.0 & 0.698 \\
\hline Teachers & 42.8 & 29.3 & 43.5 & 37.5 & 0.875 \\
\hline Staff & 61.8 & 34.4 & 65.7 & 85.8 & 0.608 \\
\hline Groups & 29.4 & 15.4 & 29.4 & 18.9 & 0.973 \\
\hline & \multicolumn{5}{|c|}{ Presence of a school garden } \\
\hline \multicolumn{6}{|l|}{ Number } \\
\hline Students & 745.0 & 530.6 & $1,020.1$ & 732.1 & $<0.001$ \\
\hline Teachers & 35.2 & 25.8 & 42.8 & 29.4 & 0.012 \\
\hline Staff & 51.4 & 31.0 & 61.8 & 34.4 & 0.005 \\
\hline Groups & 25.9 & 16.9 & 29.4 & 15.4 & 0.046 \\
\hline \multicolumn{6}{|c|}{ Interest in creating a garden ${ }^{\mathbf{b}}$} \\
\hline \multicolumn{6}{|l|}{ Number } \\
\hline Students & 984.2 & 771.1 & $1,192.9$ & 834.7 & 0.067 \\
\hline Teachers & 40.9 & 32.3 & 49.9 & 34.5 & 0.049 \\
\hline Staff & 66.1 & 68.0 & 55.0 & 32.4 & 0.206 \\
\hline Groups & 28.8 & 16.6 & 31.3 & 18.0 & 0.309 \\
\hline & \multicolumn{5}{|c|}{ Existence of plans to create a garden ${ }^{\mathbf{b}}$} \\
\hline \multicolumn{6}{|l|}{ Number } \\
\hline Students & $1,030.8$ & 880.1 & $1,038.0$ & 756.6 & 0.945 \\
\hline Teachers & 40.8 & 30.7 & 44.0 & 33.9 & 0.478 \\
\hline Staff & 61.4 & 37.1 & 64.2 & 68.8 & 0.742 \\
\hline Groups & 28.9 & 16.5 & 29.6 & 17.1 & 0.780 \\
\hline
\end{tabular}

Note: ${ }^{\text {as }}$ tudent's $t$ test. ${ }^{\mathbf{b}}$ Schools with no garden at the time of the research.

M: Mean; SD: Standard Deviation. 
Table 4. Multivariate logistical regression of the variables associated with the presence of a school garden. Distrito Federal, Brazil, 2008-2009.

\begin{tabular}{|c|c|c|c|c|c|}
\hline \multirow{2}{*}{ Variables } & \multirow{2}{*}{$\operatorname{Exp}(\beta)^{\mathbf{a}}$} & \multicolumn{2}{|c|}{$\mathrm{Cl}(95 \%)$ for $\operatorname{Exp}(\beta)$} & \multirow{2}{*}{$p^{\mathbf{b}}$} & \multirow{2}{*}{ Influence } \\
\hline & & Inferior & Superior & & \\
\hline Location: rural & 2,350 & 1,082 & 5,104 & 0.031 & Positive \\
\hline Quantity of students (in units of 100 ) & 0,940 & 0,922 & 0,959 & $<0.001$ & Negative \\
\hline
\end{tabular}

Note: ${ }^{\mathrm{a}}$ Exponential of $\beta$ - expresses the interpretation of the odds ratio. ${ }^{\mathbf{b}}$ Calculated with base in the contribution given by the variable to the model.

When designing the gardens, 36.9\% $(n=38)$ of the schools received technical instructions and $26.6 \%$ were trained in how to maintain it. There was a greater probability of the school receiving technical instructions about the garden when its implementation was approved in order to create an educational area $(p=0.01)$.

In total, $35.2 \%(n=37)$ of the schools possessed specific didactic material to maintain the garden, usually material from government institutes providing technical agricultural assistance (51.3\%). Furthermore, $68.7 \%$ of the schools stated that they had their own resources to finance the garden. However, staff (26.3\%) and the community itself $(24.2 \%)$ were also mentioned as contributors. When the reason for the creation of the garden was to work with students, there was a greater chance that the garden was funded by the school itself $(p=0.002$ ).

The main benefits reported in relation to school gardens were their contribution to healthier eating habits in the school $(74.3 \%)$, improved pedagogical aspects $(25.7 \%)$ and environmental awareness and interaction $(21.8 \%)$.

The most commonly cultivated crops were the following: condiment plants $(96.1 \%)$; greens (94.1\%); medicinal plants $(78.4 \%)$, fruit plants $(61.8 \%)$ and cereals, roots and tubers (35.3\%). Most of the schools (86.3\%) reported using the food grown in their gardens within the school. The greatest frequency of use reported was weekly (72.4\% of these schools) and $74.6 \%$ stated that they complemented school food two or three times a week.
In total, $32.4 \%$ of the schools reported some type of change in the preparation of school food after the implementation of a school garden $(p=0.015)$, highlighting the enrichment involved in the introduction of new types of food and an improvement in acceptance, smell and taste.

In $59.0 \%$ of schools with a garden, the respondents reported using it as an educational area to promote healthy eating habits on a weekly (38.7\%) or daily (32.3\%) basis. The main activities indicated were classes and dynamic activities about healthy eating habits $(69.4 \%)$, cultivating a garden (35.5\%), culinary preparations and trying the food that was cultivated (33.9\%). According to all respondents, the teachers carried out these activities. When the teachers participated in planting and cultivating the garden, there was a greater tendency for them to be used as an educational area to promote healthy eating habits on a daily or weekly basis ( $p=0.042$ ).

In total, $32.4 \%$ of the schools mentioned having an area set aside for culinary activities with food from the garden, including the canteen $(32.4 \%)$, classrooms $(29.4 \%)$ and the kitchen (26.5\%). In addition, $75.0 \%$ of the schools used the garden while discussing certain subjects, such as: science $(91.8 \%)$; mathematics $(57.5 \%)$; Portuguese $(54.8 \%)$ and geography $(32.9 \%)$. When the use of the garden as an educational area to promote healthy eating habits was correlated with its further use in association with other subjects, there was a greater probability of the teachers using the space for mathematics ( $p=0.002)$ and Portuguese $(p=0.003)$.

According to reports, management (33\%) was the school community that was least involved 
in activities related to planting and cultivating the garden. Staff ( $80 \%)$, students (78\%) and teachers $(66 \%)$ were the most involved groups. The main positive aspects of student participation in planting and cultivating the garden were the following: environmental awareness and interaction (37\%); healthier eating habits at school (33\%); improved pedagogical aspects (24\%) and human development (22\%). When students participated in planting and cultivating the garden, a collaboration was found between this strategy and the teaching/learning process $(p<0.001)$. For $82 \%$ of the respondents, the garden collaborated with the teaching/learning process $(67 \%)$.

The main difficulties regarding the implementation and maintenance of the garden were a lack of funding $(45.0 \%$ and $42.0 \%$, respectively) and a lack of manpower (34.0\% and $48.0 \%$, respectively). Due to these obstacles, $31.0 \%$ of the schools $(n=32)$ reported abandoning the garden at some stage. There was a greater chance of the garden being abandoned $(p=0.04)$ when a lack of adequate maintenance conditions were mentioned as a difficulty. In addition, when the difficulty was not a lack of time to care for the garden, the probability of the school not abandoning it was higher $(p=0.04)$. Despite the abovementioned difficulties, $30.7 \%$ of the gardens remain productive and in place for the last six years or more.

\section{DISCUSSION}

School gardens are seen as a possible method of promoting the healthy development of young people and integration with activities that stimulate healthy eating habits, as proposed by the initiative of Escolas Promotoras de Saúde (Health Promoting Schools) ${ }^{11-14}$.

The use of school gardens is not a novelty in Brazil. The Portaria Interministerial (Interministerial Ordinance) $n^{\circ}$ 1.010/2006, which instituted directives to promote healthy eating habits in schools, defined the stimulation of gardens as one of its priorities ${ }^{15}$. Furthermore, since 2005, gardens are stimulated by the Fundo Nacional de Desenvolvimento da Educação (FNDE) of the Ministério da Educacão (MEC), in partnership with the United Nations Food and Agriculture Organization (FAO), using projects that aim to incorporate healthy eating habits and environmental sustainability as generators of pedagogical practices $^{14}$.

However, there are still relatively few institutions appropriating this strategy in Brazil and investigations of the use of this type of space with students are scarce, which is a limitation of the present study in terms of possible data comparisons.

It is believed that urban schools in particular, do not have adequate space to develop a garden ${ }^{16}$. The present study shows that there is a tendency for more rural schools to have a garden, perhaps due to the availability of space or the fact that agricultural practices are more common in these areas. In fact, it also shows the existence of socio-cultural conflicts in relation to agricultural practices in urban environments ${ }^{17}$. However, most schools, urban and rural, possess the pre-requisites ${ }^{8,10}$ to cultivate a garden and in theory, could implement one. Most of the participants also stated that they were interested in this type of activity.

Contrary to the findings of the present study, a study in California found that more urban schools had gardens than rural schools: the gardens were built on the ground (69\%) and in a hanging garden fashion (60\%), which is contrary to the data referring to the availability of adequate space $^{18}$. Many spaces can be used for this type of activity, including small free spaces and squares near the school or near walls and fences ${ }^{16}$.

Schools with lower educational levels and fewer students were more likely to have a garden. Particularly in the case of smaller schools, almost a third of Australian schools that participated in a study by Somerset $\&$ Bossard ${ }^{19}$ reported using the garden extensively as a teaching instrument, whereas larger schools used their gardens in a more limited manner. 
Although not the main reason for creating a garden, the space has been used to promote food and nutritional education by $60.8 \%$ of schools in the DF. This finding is similar to that reported in an Australian study ${ }^{7}$, which highlighted the possibility of practical learning, the development of skills and a new teaching instrument, the initial aim of which was simply to create a garden. The possibility of providing nutritional education came about as a result of these activities. This confirms that the conscious use of gardens to promote healthy eating habits seems to be secondary.

Somerset \& Bossard ${ }^{19}$ reported that the initial reasons for creating a garden did not mention health directly but referred to learning about fruit, vegetables and food production. The same authors qualified these objectives as intrinsic motivational factors, associated with long-term sustained behavioral changes. These factors could be associated with high levels of utilization and a more lasting interest in the activity, since the gardens in question had been in existence for a number of years and particularly considering the appearance of gardens in the absence of any governmental instruction.

The second reason mentioned for creating a garden in the DF was to work with students, without necessarily linking this work with the possibility of food and nutritional education. The present study does not enable a detailed understanding of the respondents in terms of this possibility of working with students. Nevertheless, this option mostly referred to the educator's concern for the learner. When this was the reason for creating a garden, there was a greater chance of the school financing the project themselves.

Complementing school food was a guiding justification for creating a garden in the DF and healthier school food is cited as the main benefit of creating a garden. Significant results were found in relation to the production of condiments and vegetables for this purpose.

Similar to Portaria Interministerial (Interministerial Ordinance) $\mathrm{n}^{\circ} 1.010^{15}$, government material related to the promotion of healthy eating habits and destined for education professionals ${ }^{16}$ considers an improvement in the nutritional quality of school food as one of the main reasons for creating this strategy. Based on the reports detailing the frequency of use of vegetables produced in the garden to complement school meals, it is clear that the volume of production is not sufficient for daily needs, although this aspect was not assessed in the present study. However, the main reason for using a garden goes beyond the possible provision of vegetables for school meals. This strategy is included as a food and nutrition education activity in the Programa Nacional de Alimentação Escolar (PNAE, National School Feeding Program) to encourage the consumption and appreciation of fresh, local food with good nutritional value. The availability of these foods, in terms of the volume provided, has been established in law number 11.947/2009, which stimulates the acquisition of food from familiar agriculture ${ }^{20}$, as well as seeking to answer the abovementioned questions.

In a number of Australian schools, the food produced in the school garden exceeds the needs of the school and is also used in households ${ }^{7}$. North American studies have also reported experiences of gardens complementing school food, although those interviewed stated that the garden had not been very effective in supporting the school feeding program ${ }^{18,21}$. Although the use of gardens to complement school feeding programs was highlighted in the present study, the efficiency of this activity was not assessed.

Managers and teachers recognize that gardens reinforce healthy eating habits, although they identify poor coordination between the food program, the garden and the feeding of students ${ }^{21}$. It is believed that improvements in communication between the food service team, teachers, administrators and others involved in the garden, could help to identify strategies that would make the garden more effective in supporting the school feeding program and more adequately promote healthy eating habits. 
In the Distrito Federal, there was significant use of mathematics and Portuguese when dealing with healthy eating habits, although other subjects were also cited. A study performed with school directors in California, USA ${ }^{18}$ showed that most schools that had a garden used them for teaching $(85 \%)$, particularly in relation to science (95\%), environmental studies (70\%) and nutrition $(66 \%)$. This indicates that the gardens have been used to teach certain disciplines that are central to the standard curriculum in the USA ${ }^{18}$.

Several pedagogical activities have been carried out using school gardens, providing students with opportunities to get to know and try different types of food in natura. Although this aspect was not assessed in the present study, other studies have shown that these activities tend to encourage a preference for the consumption of fruit and vegetables 22,23 .

In the Distrito Federal, when the main reason for creating a school garden was to provide a space for food and nutritional education, the probability of the school seeking technical instruction was higher. Teacher training processes and activities developed in the classroom have the potential to stimulate healthy eating habits among schoolchildren ${ }^{24,25}$. Therefore, food and nutrition training programs must focus on the teacher in order to increase the possibility of successfully achieving the objectives of the garden project $^{26}$.

Difficulties were identified in relation to the sustainability of school gardens, particularly in terms of a lack of manpower and financial resources. These problems were also reported in the USA, in association with a lack of time on behalf of teachers and overburdened garden coordinators. These are the main challenges that need to be overcome in order to ensure the sustainability of school gardens ${ }^{18,19}$.

The lack of manpower is a direct consequence of the lack of time available to the people responsible for looking after school gardens. The fact that teachers are the people most involved, in the care and maintenance of these areas, reinforces the importance of the time factor in terms of ensuring the sustainability of the garden, as well as the fact that it can be a barrier when reduced. Therefore, there is a need for strategies that constantly involve volunteers and community members in the cultivation and maintenance of school gardens in order to prevent schoolteachers from becoming overburdened ${ }^{18}$.

According to teachers that participated in a study involving food and nutritional training, the lack of time to develop educational activities in the classroom is one of the main barriers that must be overcome. Most teachers believe that it is necessary to include a new subject in the school curriculum in order to accommodate this theme ${ }^{26}$. However, this is not the root of the issue. The appearance of the theme on a school curriculum confers legitimacy on food and nutritional education activities and reinforces the need for teachers to include this content ${ }^{16}$. Inter-disciplinary and transversal approaches, such as those standardized by the National Curricular Parameters, enable schools to work with several aspects of food and nutrition continuously, combined with the daily practices of students, and to overcome barriers between didactic disciplines. Thus, it is possible to develop the subject with the same relevance as other more conventional areas of the school curriculum ${ }^{27}$.

From the point of view of a transversal and interdisciplinary dissemination of the themes of healthy eating and nutrition, it is necessary to train educators in this area. Traditional teacher training in Brazil does not include this dimension ${ }^{27,28}$. This training could even represent a strategy of positive reinforcement for the sustainability of the garden, since the knowledge of the educators is paramount to the effectiveness of the projects implemented in schools. Training and commitment on behalf of educators tend to generate development and growth in the school community, thereby enriching the cognitive performance and participation of the learners from the social point of view of community members ${ }^{25}$. In addition, teachers agree that there is a need for further exploration of curricular resources related to the garden and its connection with traditional areas of the school curriculum ${ }^{21}$. 


\section{CONCLUSION}

In the Distrito Federal, an expressive percentage of the existence of school gardens was recorded, in line with the growing national movement encouraging this strategy.

The use of a garden as an instrument to promote healthy eating habits was most notable when the aim of the project was to complement school food. This possibility was highlighted as an initial objective of creating a garden and a strategy to promote healthy eating habits from the point of view of incentives, experimentation, consumption and value awarded to food produced in the school.

The results of the present study are indicative of the potential of gardens as an instrument to promote healthy eating habits since it deals with spaces that have entertaining features that can be applied in a transversal and multidisciplinary manner. However, the effectiveness of these actions was not assessed in the present study, since this was an initial investigative study. Further research focused on the use and impact of gardens as instruments to promote healthy eating habits among the school community is essential.

The involvement of this community, especially the teacher, is an essential component in ensuring the sustainability of the life cycle of the garden and its integration as a teaching resource. In addition, an understanding of certain characteristics of the present study, such as the location and size of schools and the different levels of education in schools, is important in the planning of strategies to extend and maintain existing gardens.

\section{CONTRIBUTORS}

All authors contributed to the conception and development of the study, data analysis, wording and revision of the final version.

\section{REFERENCES}

1. Instituto Brasileiro de Geografia e Estatística. Pesquisa de orçamentos familiares 2008-2009: análise do consumo alimentar pessoal no Brasil. Rio de Janeiro: IBGE; 2011.

2. Castro IRR, Cardoso LO, Engstrom EM, Levy RB, Monteiro CA. Vigilância de fatores de risco para doenças não transmissíveis entre adolescentes: a experiência da cidade do Rio de Janeiro, Brasil. Cad Saúde Pública. 2008; 24(10):2279-88. doi: 10.1590/S0102-311X2008001000009

3. Carmo MB, Toral N, Silva MV, Slater B. Consumo de doces, refrigerantes e bebidas com adição de açúcar entre adolescentes da rede pública de ensino de Piracicaba, São Paulo. Rev Bras Epidemiol. 2006; 9(1):121-30. doi: 10.1590/S1415-790X2006000 100015

4. Wang Y, Monteiro CA, Popkin BM. Trends of obesity and underweight in older children and adolescents in the USA, Brazil, China and Russia. Am J Clin Nutr. 2002; 75(6):971-7.

5. Monteiro CA, Benicio MHD, Konno SC, Silva ACF, Lima ALL, Conde WL. Causas do declínio da desnutrição infantil no Brasil, 1996-2007. Rev Saúde Pública. 2009; 43(1):35-43. doi: 10.1590/\$0034-89 102009000100005

6. Brasil. Ministério da Educação. Fundo Nacional de Desenvolvimento da Educação. Organização das Nações Unidas para a Agricultura e Alimentação: relatório Final. Brasília: Ministério da Educação; 2010. Relatório n UTF/BRA/067/BRA.

7. Somerset S, Ball R, Flett M, Geissman R. Schoolbased community gardens: Re-establishing healthy relationships with food. J HEIA. 2005; 12(2):25-33.

8. Lautenschlager $L$, Smith C. Beliefs, knowledge, and values held by inner-city youth about gardening, nutrition and cooking. Agric Hum Values. 2007; 24(2):245-58

9. Somerset S, Markwell K. Impact of a school-based food garden on attitudes and identification skills regarding vegetables and fruit: A 12-month intervention trial. Public Health Nutr. 2008; 12(2): 214-21. doi: 10.1017/\$1368980008003327

10. Corrêa DJ, Ming LC, Sceffer MC. Cultivo de plantas medicinais, condimentares e aromáticas. $2^{\text {a }}$ ed. Jaboticabal: Funep; 1994.

11. Brasil. Ministério da Saúde. Organização Pan-Americana da Saúde. Escolas promotoras de saúde: experiências no Brasil. Brasília: Ministério da Saúde; 2007.

12. Robinson-O'Brien R, Story M, Heim S. Impact of garden-based youth nutrition intervention programs: 
A review. J Am Diet Assoc. 2009; 109(2):273-80. doi: 10.1016/j.jada.2008.10.051

13. Food and Agricultural Organization of the United Nations. Setting up and running a school garden: Teaching toolkit. Rome: FAO; 2009.

14. Brasil. Ministério da Educação. Fundo Nacional de Desenvolvimento da Educação. Programa Nacional de Alimentação Escolar. Organização das Nações Unidas para a Agricultura e Alimentação. Mapeamento do processo: implantação e implementação do Projeto Educando com a Horta Escolar. Brasília: FNDE; 2010.

15. Brasil. Portaria Interministerial $n^{\circ} 1.010$, de 8 de maio de 2006. Institui as diretrizes para a promoção da alimentação saudável nas escolas de educação infantil, fundamental e nível médio das redes públicas e privadas, em âmbito nacional. Diário Oficial da União. 2006; 9 maio.

16. Brasil. Ministério da Saúde. Secretaria de Atenção à Saúde. Departamento de Atenção Básica. Manual operacional para profissionais de saúde e educação: promoção da alimentação saudável nas escolas. Brasília: Ministério da Saúde; 2008.

17. Silva ECR. Agricultura urbana como instrumento para a educação ambiental e para a educação em saúde: decodificando o protagonismo da escola [Dissertação]. Rio de Janeiro: Universidade Federal do Rio de Janeiro; 2010.

18. Graham H, Beall DL, Lussier M, Mclaughlin P, Zidenberg-Cherr $S$. Use of school gardens in academic instruction. J Nutr Educ Behav. 2005; 37(3):147-51.

19. Somerset S, Bossard A. Variations in prevalence and conduct of school food gardens in tropical and subtropical regions of north-eastern Australia. Public Health Nutr. 2009; 12(9):1485-93. doi: 10.10 $17 /$ 1368980008004552

20. Brasil. Lei $n^{\circ} 11.947$, de 16 de junho de 2009 . Dispõe sobre o atendimento da alimentação escolar e do programa dinheiro direto na escola aos alunos da educação básica; altera as Leis nos 10.880, de 9 de junho de 2004, 11.273, de 6 de fevereiro de 2006, 11.507, de 20 de julho de 2007; revoga dispositivos da Medida Provisória no 2.178-36, de 24 de agosto de 2001, e a Lei no 8.913, de 12 de julho de 1994; e dá outras providências. Diário Oficial da União. 2009; 17 jul; (113); Seção 1.

21. Graham H, Zidenberg-Cherr S. California teachers perceive school gardens as an effective nutritional tool do promote healthful eating habits. J Am Diet Assoc. 2005; 105(11):1797-800.

22. Morris JL, Zidenberg-Cherr S. Garden-enhanced nutrition curriculum improves fourth-grade school children's knowledge of nutrition and preferences for some vegetables. J Am Diet Assoc. 2002; 102(1):91-3.

23. McAleese JD, Rankin LL. Garden-based nutrition education affects fruit and vegetable consumption in sixth-grade adolescents. J Am Diet Assoc. 2007; 107(4):662-5.

24. Davanço GM, Taddei JAAC, Gaglianone CP. Conhecimentos, atitudes e práticas de professores de ciclo básico, expostos e não expostos a curso de educação nutricional. Rev Nutr. 2004; 17(2):177-84. doi: 10.1590/S1415-52732004000200004

25. Schmitz BAS, Recine E, Cardoso GT, Silva JRM, Amorim NFA, Bernardon R, et al. A escola promovendo hábitos alimentares saudáveis: uma proposta metodológica de capacitação para educadores e donos de cantina escolar. Cad Saúde Pública. 2008; 24(2):312-22. doi: 10.1590/\$0102$311 \times 2008001400016$

26. Bernardon R, Silva JRM, Cardoso GT, Monteiro RA, Amorim NFA, Schmitz BAS, et al. Construção de metodologia de capacitação em alimentação e nutrição para educadores. Rev Nutr. 2009; 22(3): 389-98. doi: 10.1590/S1415-52732009000300 009

27. Brasil. Ministério da Educação. Secretaria de Educação Fundamental. Parâmetros Curriculares Nacionais: introdução aos PCN. Brasília: Ministério da Educação; 1997.

28. Mohr A, Schall VT. Rumos da educação em saúde no Brasil e sua relação com a educação ambiental. Cad Saúde Pública. 1992; 8(2):199-203.

Received on: 3/27/2013 Final version on: $2 / 3 / 2014$ Approved on: 2/26/2014 